\title{
STUDIES ON THE SEASONAL CHANGES IN THE CHEMICAL CONSTITUENTS OF THE PEARL OYSTER
}

\section{$\operatorname{AUTHOR}(\mathrm{S}):$}

Tanaka, Shozo; Hatano, Hiroyuki

\section{CITATION:}

Tanaka, Shozo ... [et al]. STUDIES ON THE SEASONAL CHANGES IN THE CHEMICAL CONSTITUENTS OF THE PEARL OYSTER. PUBLICATIONS OF THE SETO MARINE BIOLOGICAL LABORATORY 1952, 2(2): 341-355

\section{ISSUE DATE:}

1952-10-05

URL:

http://hdl.handle.net/2433/174670

RIGHT: 


\title{
STUDIES ON THE SEASONAL CHANGES IN THE CHEMICAL CONSTITUENTS OF THE PEARL OYSTER*
}

\author{
Shozo TANAKA and Hiroyuki HATANO \\ Biochemical Laboratory, Faculty of Science, Kyoto University
}

With 8 Text-figures and 10 Tables

Not only in morphology but also in metabolism many marked differences have been observed between Invertebrata and Vertebrata. Especially differences in the chemical process of calcification are typical. The mechanism of shell formation by the mollusks, however, has not yet been so thoroughly studied as the process of bone formation.

Although a sort of pearls is produced by many kinds of bivalved mollusks, that of the pearl oyster, Pinctada martensiz, is said to be superior. In the culture pearl industry of Japan, this kind of mollusk has been used almost exclusively (1) (2).

It may be expected that the quality of the pearl formed by the pearl oyster is influenced by various external conditions under which the pearl oysters have been cultivated. For several years the process of calcification in the pearl oyster has been studied from the biochemical standpoint at this laboratory (3). The seasonal variations in the chemical constituents of the pearl oyster were first investigated. Especially, since the inorganic constituents are presumed to have close relation to the formation of the pearl and of the shell, their seasonal changes were precisely investigated.

\section{EXPERIMENTAL}

\section{Materials}

The pearl oysters used in these studies were two- or three-winter mollusks cultivated at the beach of The Seto Marine Biological Laboratory of The Kyoto University at Shirahama Town in Wakayama Prefecture.

* Report of the Nippon Institute for Scientific Research on Pearl. No. 19.

Publ. Seto Mar. Biol. Lab., II. (2), 1952. (Article 21) 
Analysis were performed once a month from October to the following September. For the determination of glycogen content several oysters were treated at The Marine Laboratory and the rest were brought to The Biochemical Laboratory of The Kyoto University and a measurement of other constituents was conducted.

\section{Methods}

To determine the total weight, fresh meat and dried meat, water content, total nitrogen, lipids, glycogen and ash, fifteen oysters were used each time. The analysis of each constituent was carried out as follows (4).

Water (Moisture) and ash: Adductor muscles were separated from other parts and were dried at room temperature between filter papers. Water content was estimated from the decrease of weight after drying the meat at $105^{\circ}$ to $110^{\circ} \mathrm{C}$. in the oven. Dried meat was burnt to ashes in the muffle.

Total nitrogen (5): Total nitrogen was determined by KJELDAHL's method using metallic selenium as completely oxidizing catalyst.

Lipids: Lipids were extracted with ether by using SoxhLET's extractor for about sixteen hours from the dried meat, dehydrated in vacuum at $40^{\circ}$ $45^{\circ} \mathrm{C}$. for about six hours.

Glycogen (6): Since glycogen content in the pearl oyster is reported to be variable during the day (7), six oysters were taken up from the sea at 9 a.m. each time for the determination of glycogen content. As soon as possible glycogen was isolated from the fresh meats by means of PFLEGER's method and was hydrolysed with $\mathrm{HCl}$. The amounts of glucose thus formed were determined by FEHLING-LEHMANN-SHOORL'S method and the glycogen content was calculated.

Inorganic constituents (8): For the determination of the inorganic constituents, ashes from the dried meats of thirty oysters were used. The ash was treated with $\mathrm{HCl}$ and after filtrating the trace amount of silica separated, phosphate was precipitated by ammonium molybdate. From this filterate iron and aluminium were precipitated by the addition of ammonia water. Calcium and magnesium were determined as oxalate and phosphate respectively with the filtrate from iron. With the solution free from phosphate, sulphate, magnesium, iron, aluminium and manganese by baryta, the determination of alkali metals was carried out by the platinium chloride method and also by the magnesium uranyl acetate method. Sulphate was measured as barium sulphate and chloride was also determined by the silver chloride method. 


\section{RESULTS AND DISCUSSION}

Seasonal changes of the average values of total weight, of weight of the shell, of the fresh meat and of the dried meat, and content of water per oyster are shown in Table $\mathrm{I}$ and Fig. 1.

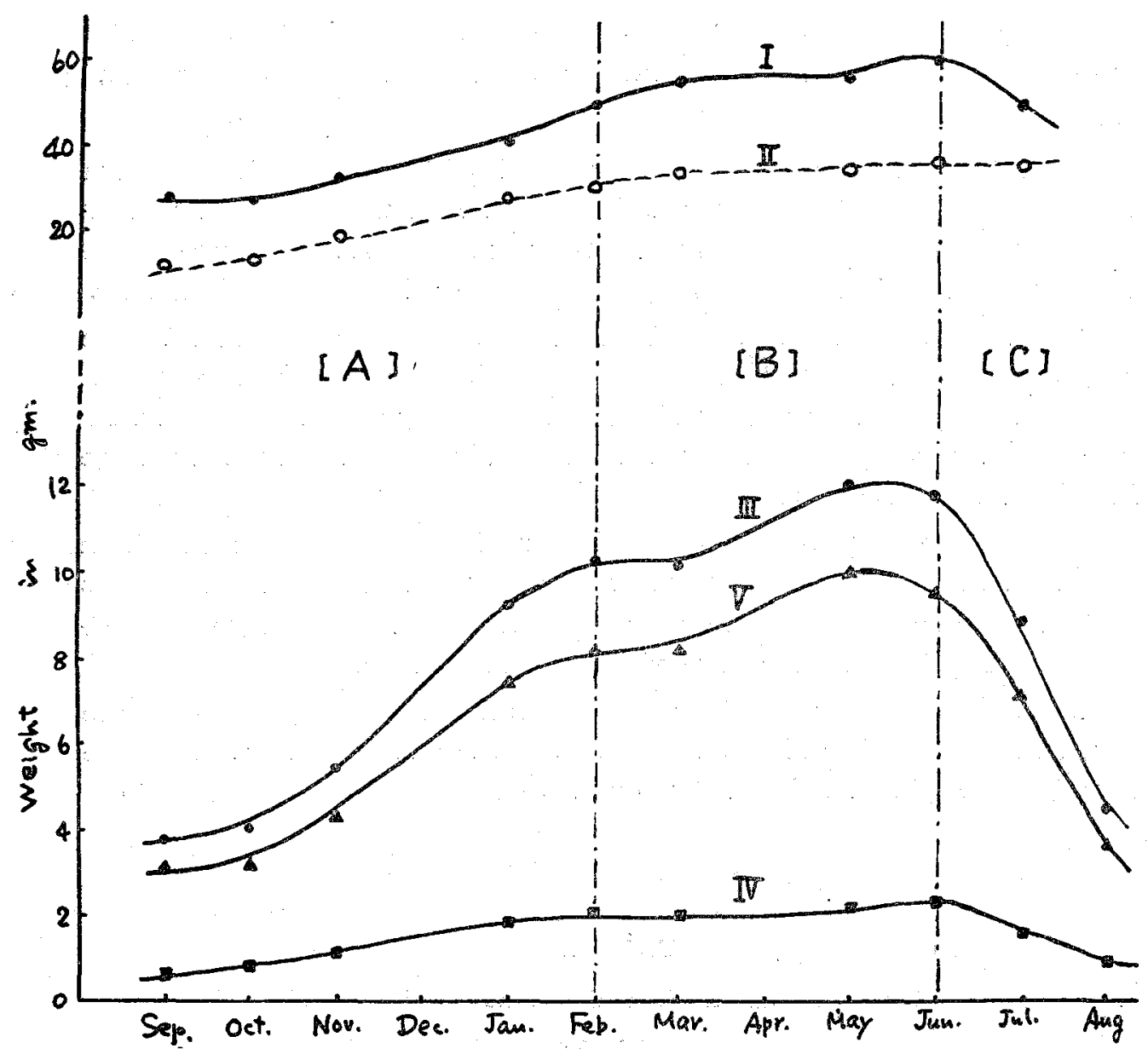

Fig. 1. The Monthly Changes in the Weight of the Pearl Oyster (per a Pearl Oyster). Curve I : Total weight, II: Shell weight, III: Fresh meat weight, IV : Dried meat weight and $\mathrm{V}$ : Water content. Period [A]: The fattening period, [B]: The ripening period and [C]: The reproductive period.

Table I.

The Monthly Changes in the Weight of the Pearl Oyster

(per a Pearl Oyster). 


$\begin{array}{lrrrrrrrrr} & \text { Sep. } & \text { Oct. } & \text { Nov. } & \text { Jan. } & \text { Feb. } & \text { Mar. } & \text { May } & \text { Jun. } & \text { Jul. } \\ & \mathrm{g} & \mathrm{g} & \mathbf{g} & \mathrm{g} & \mathrm{g} & \mathrm{g} & \mathrm{g} & \mathrm{g} & \mathrm{g} \\ \text { Total weight } & 27.0 & 26.4 & \mathbf{3 3 . 6} & 41.5 & 50.4 & 565 & 56.0 & 61.5 & 51.0 \\ \text { Shell weight } & 13.1 & 12.4 & 18.6 & 286 & 30.7 & 34.7 & 34.8 & 38.1 & 35.7 \\ \text { Fresh meat weight } & 3.83 & 3.98 & 54.8 & 9.31 & 10.28 & 10.10 & 12.11 & 11.36 & 8.84 \\ \text { Dried meat weight } & 0.64 & 0.77 & 1.14 & 1.78 & 2.05 & 2.00 & 2.17 & 2.32 & 1.60 \\ \text { Water content } & 3.18 & 3.22 & 4.34 & 7.53 & 823 & 8.10 & 9.95 & 9.55 & 7.24\end{array}$

Remarkable increases in total weight and weight of the shell through out these experiments were observed. Fresh and dried meat increased gradually from September to the following June in weight. A sudden decrease to the extent of about half of weight in May was observed to occur in summer.

From these facts, the season from autumn to winter is presumed to be the fattening period of the pearl oyster, which in spring the vegetative growth ceases and the gonads gradually ripen (the ripening period). The summer is the reproductive period, when gonads have fully ripened and the discharge of the sexual products occurs.

It is noteworthy that in spite of decrease in the weight of the fresh meat, dried meat increases in weight during May and June. This fact shows that hydrolysis or other chemical reactions which need water may take place in the oyster before the discharge of the sexual products.

The monthly changes in the chemical constituents of the pearl oyster are shown in Table II-VII and Fig. 2-6. Those of the adductor muscle alone are shown in Table V and VII and Fig. 5 and 6.

Table II.

The Monthly Changes in the Chemical Constituents of the Pearl Oyster

(in Weight).

\begin{tabular}{|c|c|c|c|c|c|c|c|c|c|c|}
\hline & $\begin{array}{c}\text { Sep. } \\
g\end{array}$ & $\begin{array}{r}\text { Oct. } \\
\mathrm{g}\end{array}$ & $\begin{array}{c}\text { Nov. } \\
\mathrm{g}\end{array}$ & $\begin{array}{c}\text { Jan. } \\
\mathrm{g}\end{array}$ & $\begin{array}{c}\text { Feb. } \\
\mathrm{g}\end{array}$ & $\begin{array}{c}\text { Mar. } \\
\mathrm{g}\end{array}$ & $\begin{array}{c}\text { May } \\
\text { g }\end{array}$ & $\begin{array}{r}\text { Jun } \\
\mathrm{g}\end{array}$ & $\begin{array}{r}\text { Jul. } \\
\mathrm{g}\end{array}$ & $\begin{array}{c}\text { Aug. } \\
\mathrm{g}\end{array}$ \\
\hline Total nitrogen & 0.080 & 0078 & 0.130 & 0.200 & 0.208 & 0.222 & 0.233 & 0.262 & 0.188 & 0.105 \\
\hline Crude protein & 0.500 & 0.487 & 0.810 & 1.246 & 1.297 & 1.400 & 1.589 & 1.635 & 1.177 & 0.657 \\
\hline Lipids & 0.059 & 0.084 & 0.102 & 0.191 & 0.241 & 0.110 & 0.094 & 0.113 & 0.058 & 0.073 \\
\hline Glycogen & 0.003 & $0: 033$ & 0.079 & 0.150 & 0.176 & 0.264 & 0.150 & 0.163 & 0.110 & 0.011 \\
\hline Total ash & 0.077 & 0.088 & 0.096 & $0.101:$ & 0.162 & 0.188 & 0.162 & 0.189 & 0.154 & 0.094 \\
\hline
\end{tabular}




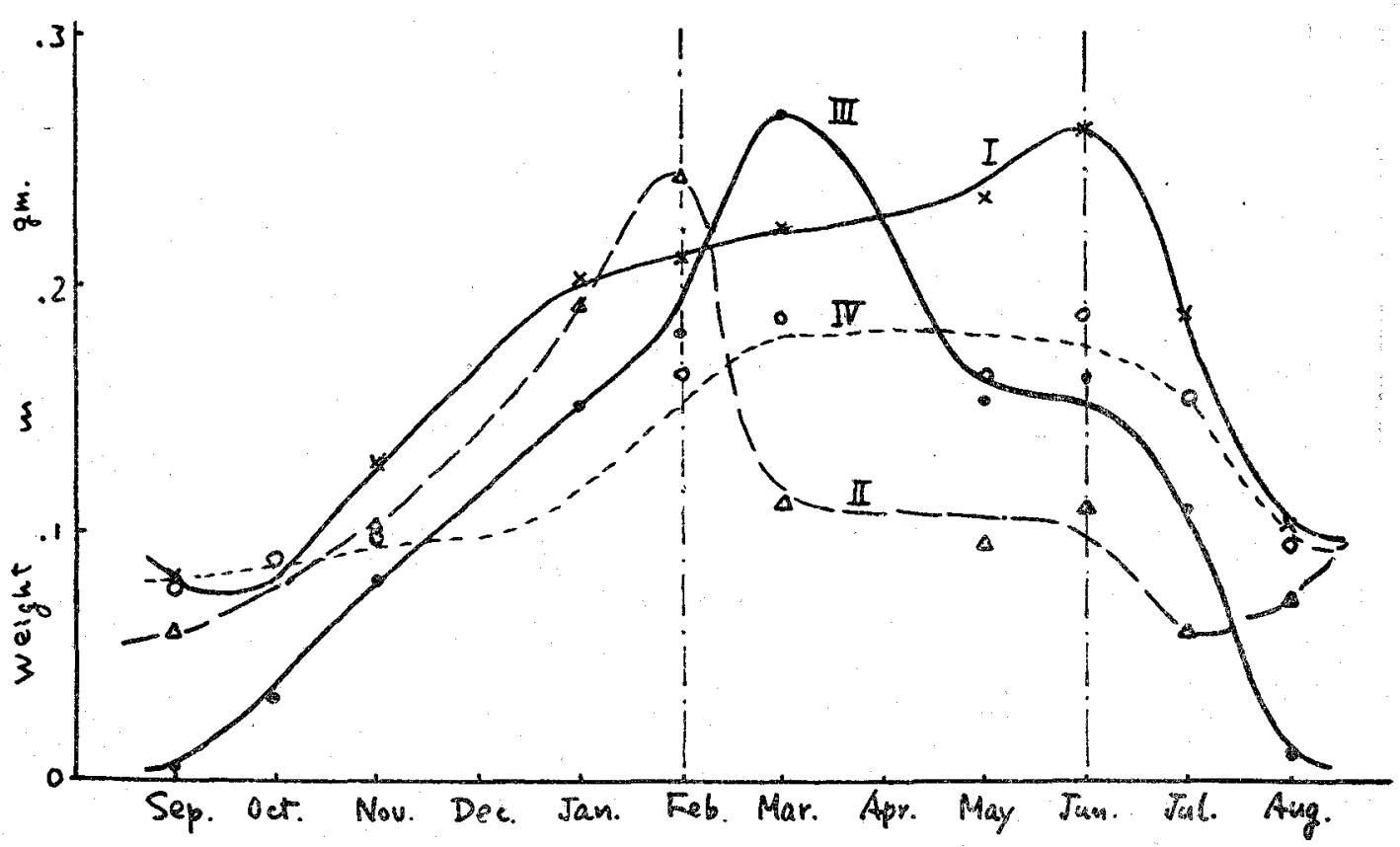

Fig. 2. The Monthly Changes in the Chemical Constituents of the Pearl Oyster (in Weight). Curve I: Total nitrogen, II : Lipids, III : Glycogen and IV : Total ash.

Table III.

The Monthy Changes in the Chemical Constituents of the Pearl Oyster

(in Percentage).

$\begin{array}{lcccccccccc} & \text { Sep. } & \text { Oct. } & \text { Nov. } & \text { Jan. } & \text { Feb. } & \text { Mar. } & \text { May } & \text { Jun. } & \text { Jul. } & \text { Aug. } \\ & \% & \% & \% & \% & \% & \% & \% & \% & \% & \% \\ \text { Water } & 83.24 & 80.56 & 79.40 & 81.20 & 79.85 & 78.11 & 81.50 & 80.22 & 81.57 & 80.54 \\ \text { Dried meat } & 16.76 & 19.44 & 20.60 & 18.80 & 20.15 & 21.89 & 18.50 & 19.78 & 18.43 & 19.46 \\ \text { Total nitrogen } & 12.50 & 10.13 & 11.39 & 11.21 & 10.13 & 11.10 & 11.72 & 12.28 & 11.76 & 12.23 \\ \text { Crude protein } & 7820 & 63.31 & 71.16 & 70.06 & 63.30 & 70.00 & 73.24 & 70.50 & 73.52 & 76.45 \\ \text { Lipids } & 9.20 & 10.90 & 8.91 & 10.70 & 11.77 & 5.48 & 435 & 4.88 & 3.60 & 8.52 \\ \text { Glycogen } & 0.40 & 3.93 & 6.90 & 8.40 & 8.57 & 13.18 & 8.91 & 7.02 & 657 & 1.24 \\ \text { Total ash } & 12.10 & 11.41 & 8.40 & 5.65 & 7.90 & 9.41 & 7.46 & 813 & 9.63 & 10.85\end{array}$




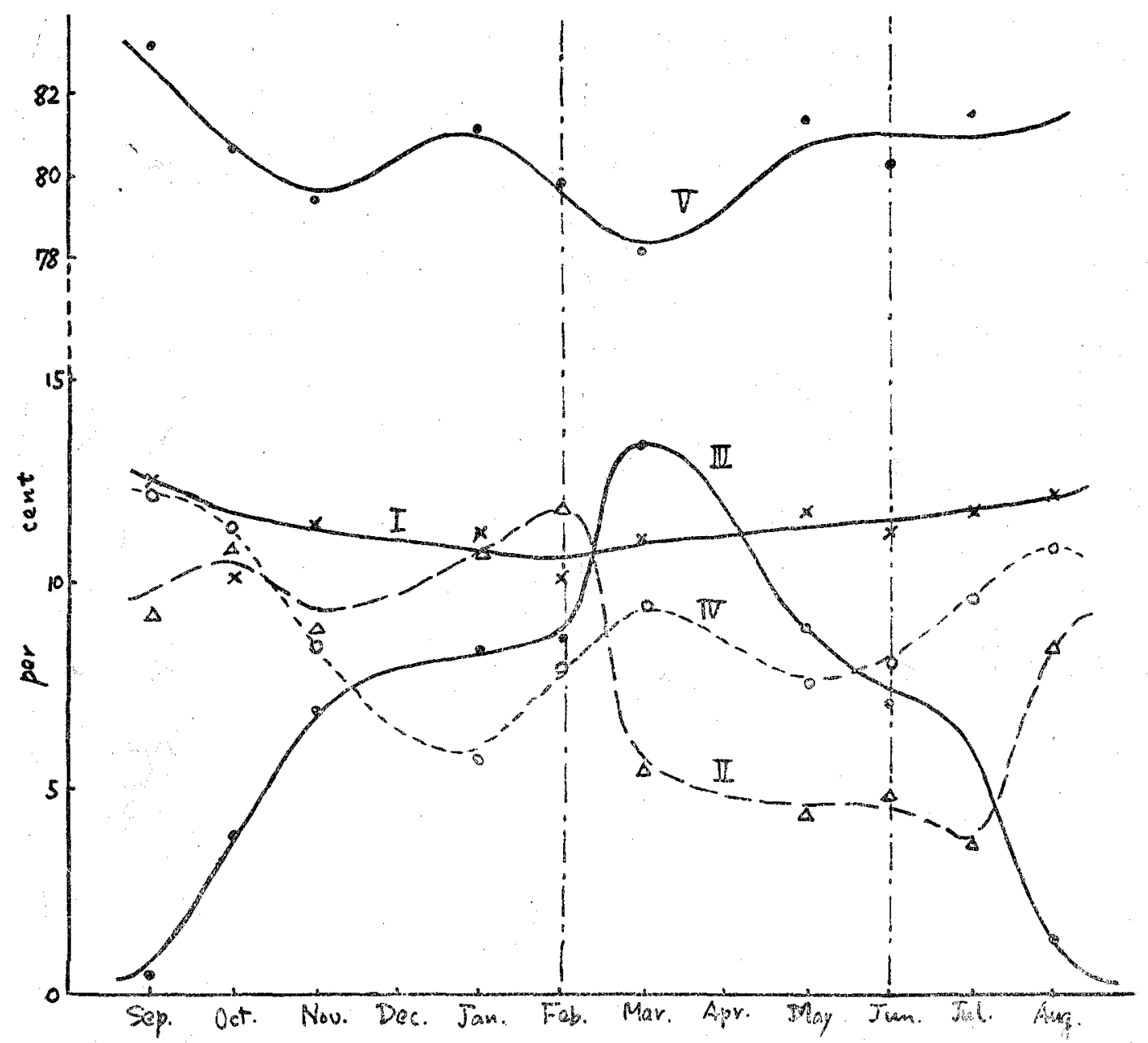

Fig. 3. The Monthly Changes in the Chemical Constituents of the Pearl Oyster in Percentage). Curve I: Total nitrogen, II: Lipids, III : G'ycogen and IV: Total ash to Dried meat). Curve V: Water (to Fresh meat).

Table TV.

The Monthly Changes in the Chemical Constituents of Body without Adductor Muscle (in Weight).

$\begin{array}{lcccccccc} & \text { Nov. } & \text { Jan. } & \text { Feb. } & \text { Mar. } & \text { May } & \text { Jun. } & \text { Jul. } & \text { Aug. } \\ & \mathrm{g} & \mathrm{g} & \mathrm{g} & \mathrm{g} & \mathrm{g} & \mathrm{g} & \mathrm{g} & \mathrm{g} \\ \text { Fresh meat } & 3.90 & 6.76 & 7.20 & 7.15 & 8.54 & 8.82 & 6.70 & 3.42 \\ \text { Water } & 3.13 & 5.61 & 5.86 & 5.70 & 7.15 & 7.13 & 5.54 & 2.78 \\ \text { Dried meat } & 0.77 & 1.15 & 1.33 & 1.30 & 1.44 & 1.68 & 1.16 & 0.62 \\ \text { Total nitrogen } & 0.087 & 0.130 & 0.136 & 0.151 & 0.170 & 0.191 & 0.133 & 0.071\end{array}$


Chemical Constituents of the Pearl Oyster

$\begin{array}{lllllllll}\text { Crude protein } & 0.542 & 0.812 & 0.848 & 0.945 & 1.060 & 1.192 & 0.828 & 0.441 \\ \text { Lipids } & 0.081 & 0.127 & 0.157 & 0.104 & 0.096 & 0.111 & 0.059 & 0.065 \\ \text { Glycogen } & 0.037 & 0.093 & 0.106 & 0.073 & 0.059 & 0.034 & 0.041 & 0.004 \\ \text { Total ash } & 0.070 & 0.080 & 0.131 & 0.154 & 0.131 & 0.149 & 0.130 & 0.079\end{array}$

Table V.

The Monthly Changes in the Chemical Constituents of Adductor Muscle (in Weight).

Nov. Jan. Feb. Mar. May Jun. Jul. Aug.

$\begin{array}{lllllllll} & \mathrm{g} & \mathrm{g} & \mathrm{g} & \mathrm{g} & \mathrm{g} & \mathrm{g} & \mathrm{g} & \mathrm{g} \\ \text { Fresh meat } & \mathbf{1 . 5 8} & 2.55 & 3.08 & 2.95 & 3.57 & 3.04 & 2.14 & 1.07 \\ \text { Water } & 1.21 & 1.92 & 2.37 & 2.40 & 2.80 & 2.42 & 1.70 & 0.83 \\ \text { Dried meat } & 0.37 & 0.63 & 0.72 & 0.70 & 0.73 & 0.64 & 0.44 & 0.24 \\ \text { Total nitrogen } & 0.043 & 0.056 & 0.073 & 0.073 & 0.085 & 0.072 & 0.053 & 0.032 \\ \text { Crude protein } & 0.267 & 0.417 & 0.455 & 0.456 & 0.532 & 0.449 & 0.340 & 0.201 \\ \text { Lipids } & 0.021 & 0.061 & 0.022 & 0.020 & 0.017 & 0.019 & 0.009 & 0.010 \\ \text { Glycogen } & 0.040 & 0.057 & 0.081 & 0.171 & 0.084 & 0.127 & 0.061 & 0.007 \\ \text { Total ash } & 0.024 & 0.025 & 0.041 & 0.043 & 0.040 & 0.04 .0 & 0.030 & 0.020\end{array}$

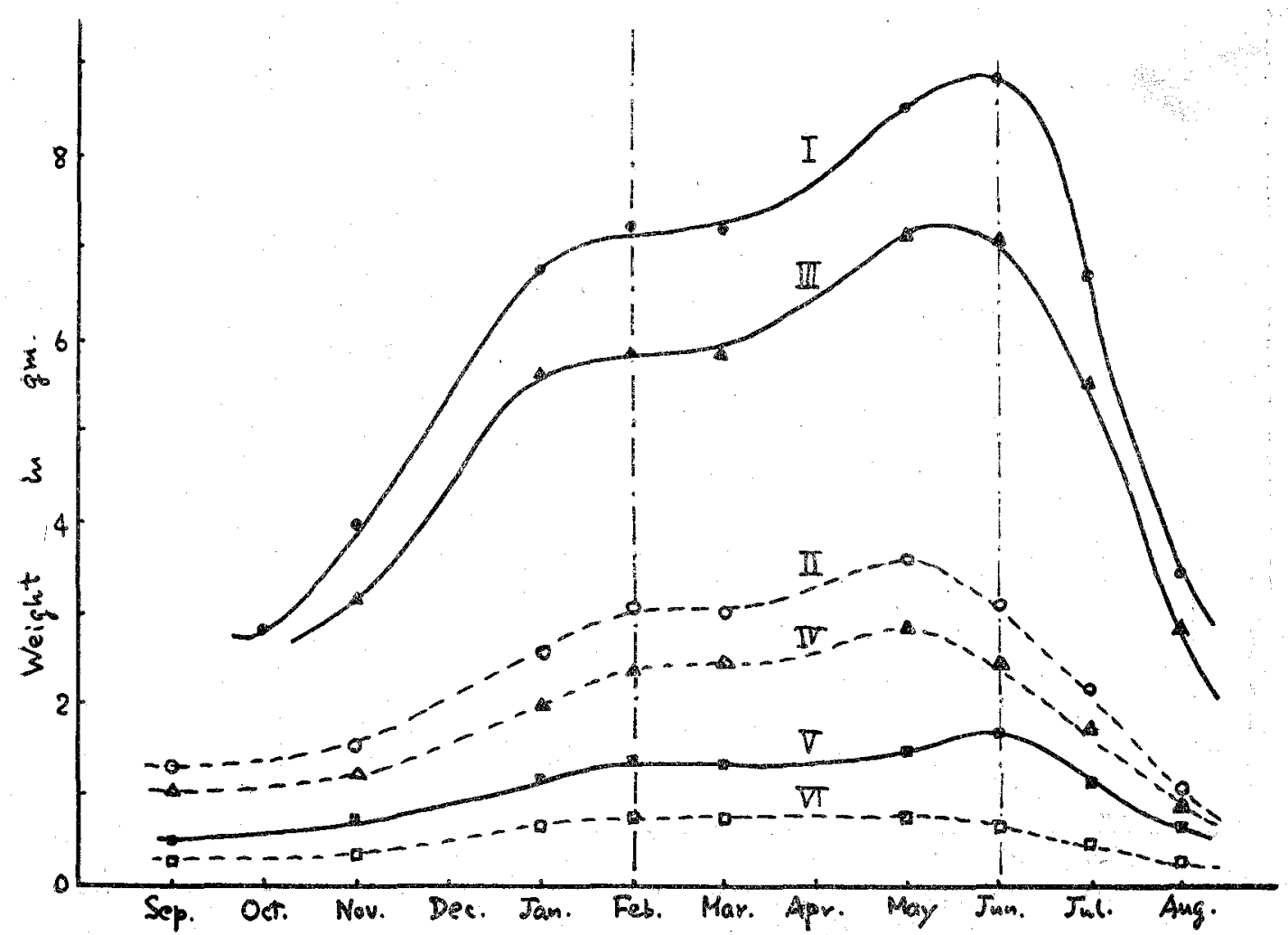

Fig. 4. The Monthly Changes in the Weight of Adductor Muscle and Toial Other Parts of the Body of the Pearl Oyster. Curve I; Fresh meat in Body, II : Fresh meat in Adductor Muscle, III: Water in Body, IV: Water in Adductor Muscle, V: Dried meat in Body and VI; Dried meat in Adductor Muscle.

$$
-307-
$$



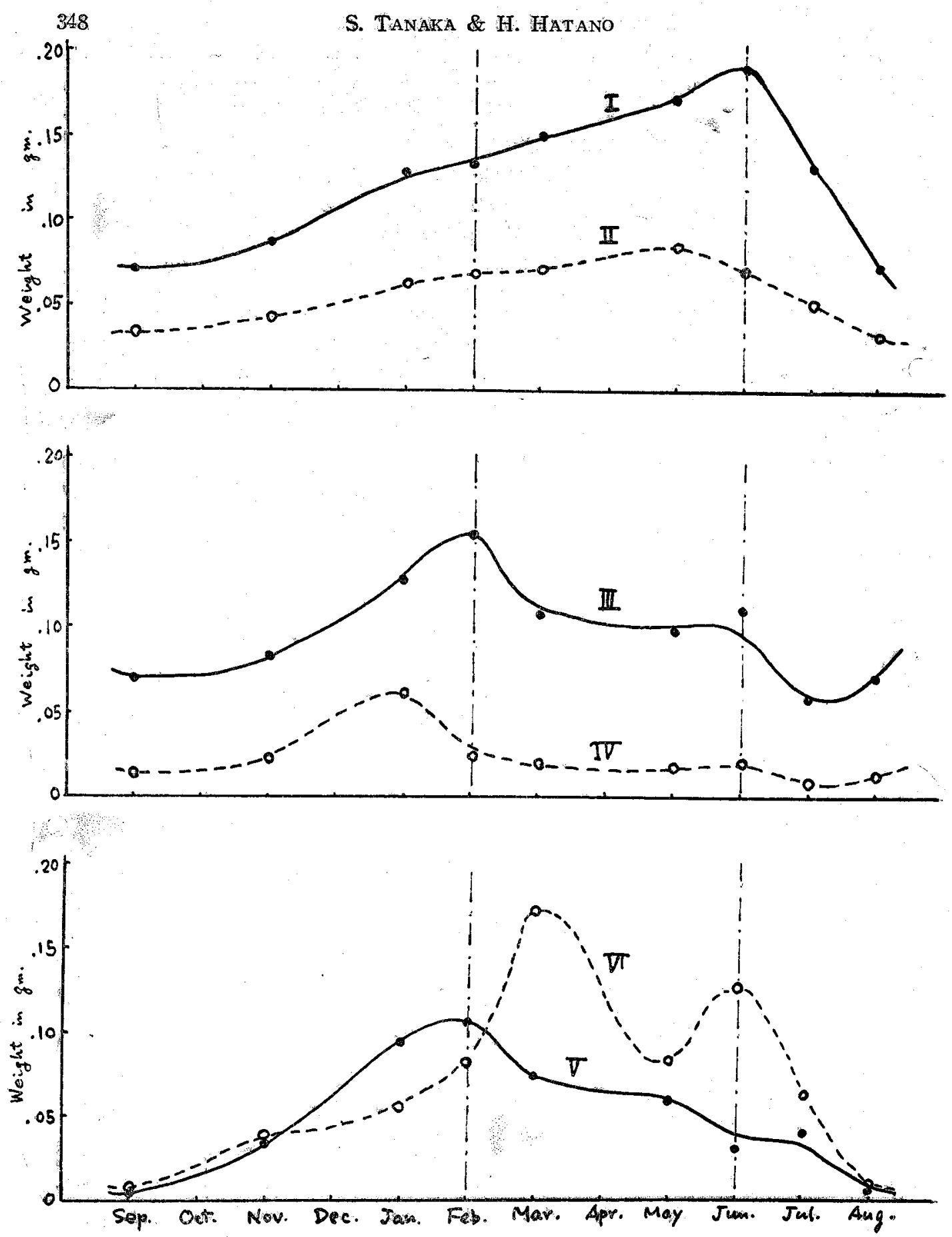

Fig. 5. The Monthiy Changes in the Weight of Total Nitrogen, Lipids and Glycogen of the Addnctor Muscle and Total Oher Parts of the Body of the Pearl Oyster. Curve I; Total nitrogen in Body, II: Total nitrogen in Alductor Muscle, III : Lipids in Body, IV: Lipids in Addicter Muscle, V: Glycogen in Body and VI: Glyeagen in Adductor Muscle. 
Table VI.

The Monthly Changes in the Chemical Constituents of Body without Adductor Muscle (in Percentage).

$\begin{array}{lcccccccc} & \text { Nov. } & \text { Jan. } & \text { Feb. } & \text { Mar. } & \text { May } & \text { Jun. } & \text { Jul. } & \text { Aug. } \\ & \% & \% & \% & \% & \% & \% & \% & \% \\ \text { Water } & 80.22 & 82.95 & 81.44 & 80.65 & 83.05 & 80.86 & 82.69 & 81.88 \\ \text { Dried meat } & 19.78 & 17.04 & 18.56 & 19.34 & 16.95 & 19.14 & 17.31 & 18.12 \\ \text { Total nitrogen } & 11.26 & 11.30 & 10.20 & 11.63 & 11.78 & 11.36 & 11.43 & 11.38 \\ \text { Crude protein } & 70.40 & 70.63 & 63.75 & 72.65 & 73.60 & 71.00 & 71.40 & 71.15 \\ \text { Lipids } & 10.51 & 11.03 & 11.82 & 8.03 & 6.69 & .6 .58 & 5.10 & 10.52 \\ \text { Glycogen } & 4.81 & 8.07 & 7.93 & 5.58 & 4.07 & 2.02 & 3.51 & 0.56 \\ \text { Total ash } & 9.04 & 6.99 & 9.84 & 11.87 & 9.11 & 8.85 & 11.19 & 12.67\end{array}$

Table VII

The Monthly Changes in the Chemical Constituents of Adductor Muscle

(in Percentage).

Nov. Jan. Feb. Mar. May Jun. Jul. Aug.

$\begin{array}{lcccccccc} & \% & \% & \% & \% & \% & \% & \% & \% \\ \text { Water } & 76.31 & 75.31 & 76.98 & 75.31 & 79.22 & 79.62 & 79.32 & 77.35 \\ \text { Dried meat } & 23.69 & 24.68 & 23.01 & 24.69 & 20.78 & 20.38 & 20.68 & 22.65 \\ \text { Total niirogen } & 11.56 & 10.41 & 10.11 & 10.41 & 11.65 & 11.21 & 12.10 & 13.36 \\ \text { Crude protein } & 72.25 & 65.15 & 63.20 & 65.15 & 72.85 & 70.10 & 75.65 & 83.50 \\ \text { Lipids } & 5.63 & 9.59 & 2.98 & 2.83 & 2.27 & 3.01 & 2.01 & 4.31 \\ \text { Glycogen } & 10.93 & 8.95 & 11.29 & 24.38 & 11.45 & 19.82 & 13.81 & 3.05 \\ \text { Total ash } & 6.36 & 3.98 & 5.65 & 6.15 & 5.44 & 6.23 & 6.84 & 8.14\end{array}$



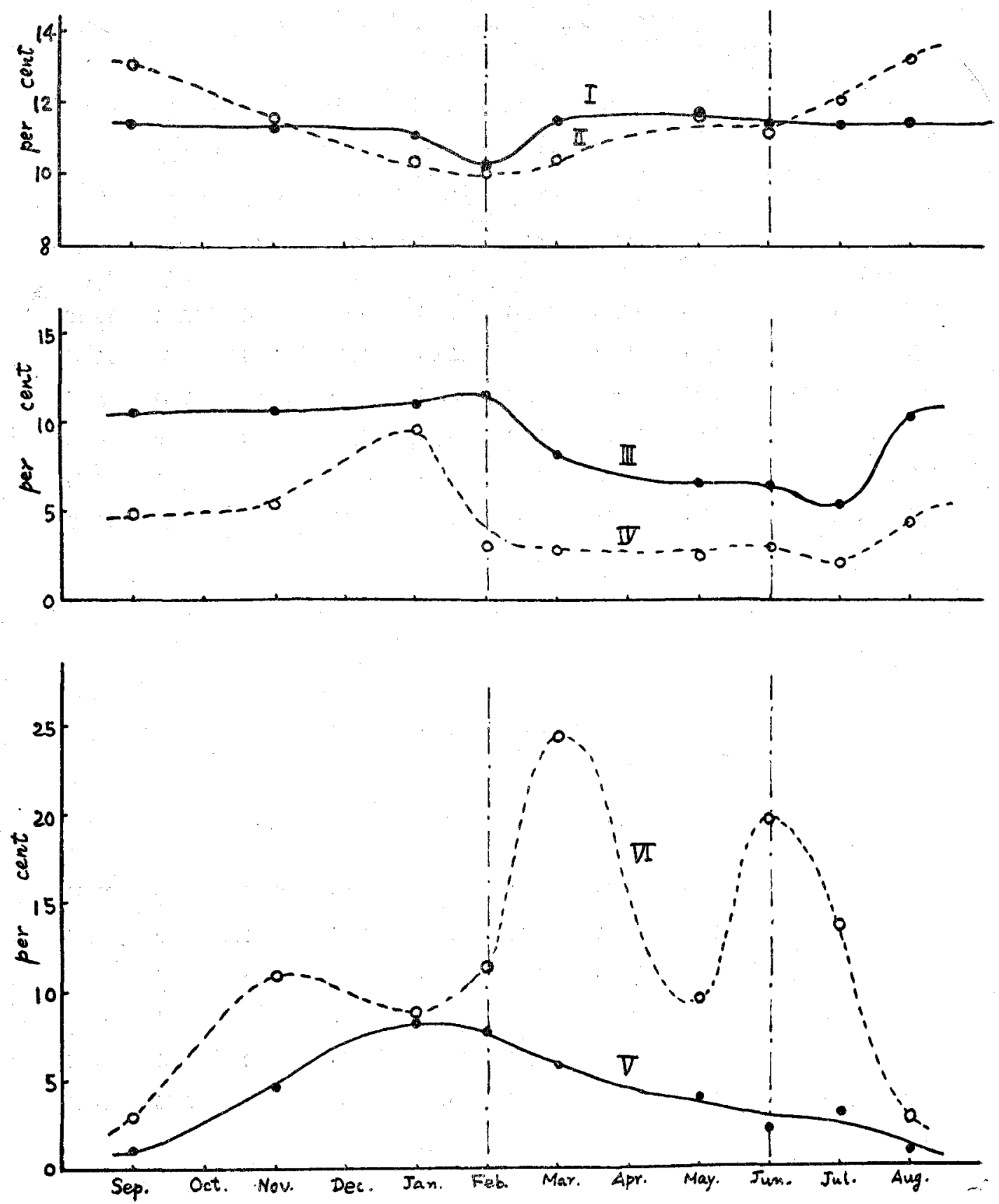

Fig. 6. The Monthly Changes in Percentage of Total Nitrogen, Lip:ds and Glycogen of the Adductor Muscle and Total Other Parts of the Body of the Pearl Oyster. Curve I: Total nitrogen in Body, II : Total nitrogen in Adductor Muscle, III: Lipids in Body, IV: Lipids in Adductor Muscle, V: Glycogen in Body and VI: Glycogen in Adductor Muscle. 
Seasonal changes in protein content, which is the main component of the meat and of the adductor muscle, were found to be less striking than those occurring in other components, such as glycogen and lipids.

In the beginning of the fattening period the storage of glycogen is very remarkable. Notwithstanding that only trace glycogen was contained in September it increased rapidly and reached its maximum content (15\%) at the end of the fattening period. Especially in February glycogen was observed to be accumulated in the meat (except the adductor muscle) and then transferred into the adductor muscle in March. In contrast to the continuous increase in meat, glycogen begins to decrease gradually till May or June. From these facts certain active substances required for reproduction may be produced in this ricening period with the energy evolved from the oxidation of glycogen.

Lipids were also observed to be accumulated in the fattening period and reach maximum content in January in the adductor muscle and in February in the meat respectively. It is supposed from the facts that like glycogen lipids are utilized as sources of energy required for reproductive activities. The variation curves of lipids and glycogen suggest that transformations of lipids to glycogen may take place in the mollusk.

In contrast to the near-exhaustion of glycogen at the end of the ripening period, definite amounts of the lipids were noticed as still remaining. These constant lipids are presumed to have some physiological significance.

The results of analysis of the adductor muscle show that this organ serves not only to open and to shut the shell but also as a storage device of the oyster.

In contrast to the decrease of ash content a remarkable increase in shell weight was observed in the autumn. The season of pearl formation in the oyster is supposed to coincide with this season.

The seasonal changes in calcium, magnesium, iron, potassium, sodium, phosphate, chloride and sulphate content are shown in Table VIII and IX and also Fig. 7 and 8.

Table VIII.

The Monthly Changes in the Inorganic Constituents of the Pearl Oyster

(in Weight).

\begin{tabular}{|c|c|c|c|c|c|c|c|c|c|c|}
\hline & $\begin{array}{c}\text { Sep. } \\
\text { mg }\end{array}$ & $\begin{array}{l}\text { Oct. } \\
\text { mg }\end{array}$ & $\begin{array}{c}\text { Nov. } \\
\text { mg }\end{array}$ & $\begin{array}{l}\text { Jan. } \\
\text { mg }\end{array}$ & $\begin{array}{c}\text { Feb. } \\
\text { mg }\end{array}$ & $\begin{array}{c}\text { Mar. } \\
\text { mg }\end{array}$ & $\begin{array}{l}\text { May } \\
\text { mg }\end{array}$ & $\begin{array}{l}\text { Jun. } \\
\text { mg }\end{array}$ & $\begin{array}{l}\text { Jul. } \\
\text { mg }\end{array}$ & $\begin{array}{l}\text { Aug. } \\
\text { mg }\end{array}$ \\
\hline $\mathrm{P}_{2} \mathrm{O}_{3}$ & 8.3 & 12.2 & 11.9 & 12.0 & 18.4 & 20.7 & 15.4 & 20.2 & 19.0 & 12.9 \\
\hline $\mathrm{CaO}$ & 7.3 & 7.8 & 9.7 & 11.0 & 17.0 & 18.3 & 16.6 & 21.1 & 16.5 & 10.6 \\
\hline $\mathrm{MgO}$ & 4.3 & 5.0 & 5.6 & 5.9 & 9.5 & 11.1 & 8.1 & 10.8 & 8.1 & 4.1 \\
\hline $\mathrm{Fe}_{2} \mathrm{O}_{3}$ & 1.2 & 1.2 & 1.6 & 2.0 & 4.1 & 6.2 & 4.2 & 4.3 & 3.5 & 1.4 \\
\hline
\end{tabular}




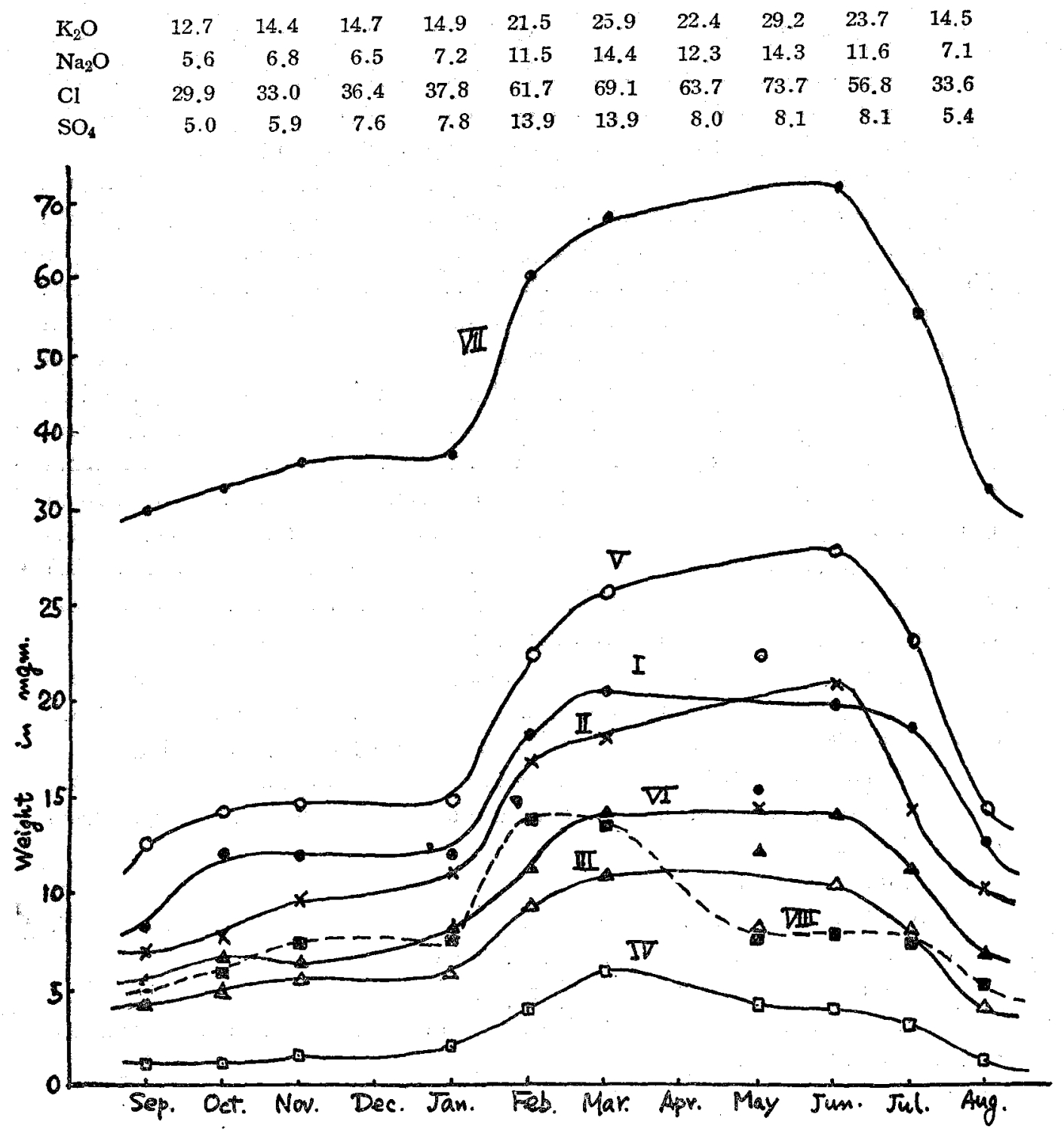

Fig. 7. The Monthly Changes in the Inorganic Constituents of the Pearl Oyster (in Weight,. Curve I: Phosphate, II : Calcium, IIl: Magnesium, IV : Iron, V: Potassium, VI: Sodium, VII: Chlo:ide and VIII: Sulphate.

Table IX.

The Monthly Changes in the Inorganic Constituents of the Pearl Oyster (in Percentage).

Sep. Ozt. Nov. Jan. Feb. Mar. Apr. May Jun. Jul. Aug.

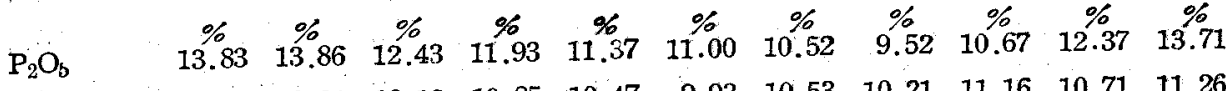

$\begin{array}{lllllllllllll}\mathrm{CaO} & & 9.48 & 8.80 & 10.12 & 10.85 & 10.47 & 9.93 & 10.53 & 10.21 & 11.16 & 10.71 & 11.26\end{array}$ 


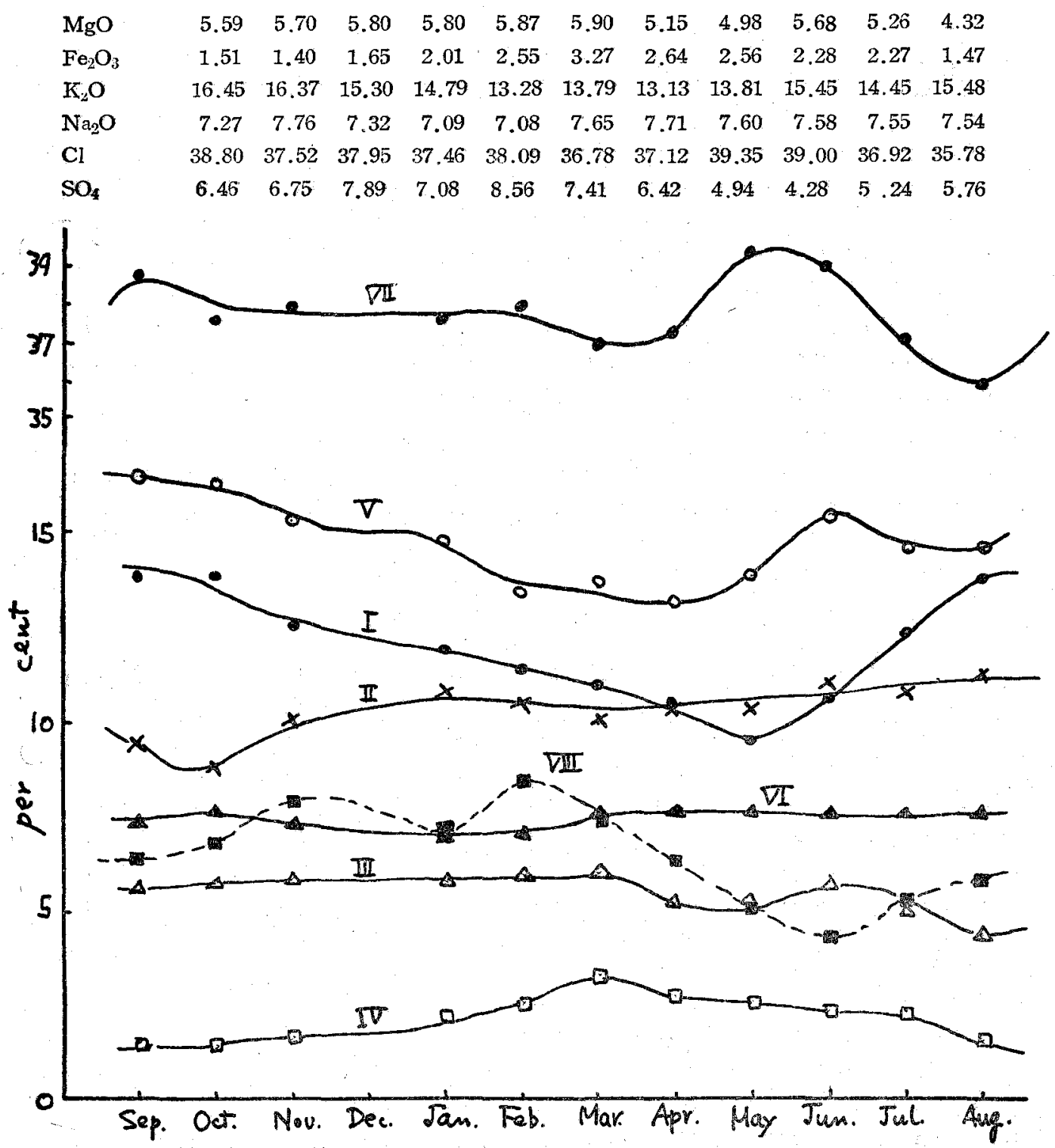

Fig. 8. The Monthly Changes in the Inorganic Constituents of the Pearl Oyster (in Percentage). Curve I: Phosphate, II: Calcium, III: Magnesium, IV : Iron, V: Potassium, VI : Sodium, VII : Chloride and VIII: Sulphate.

Total ash content of the pearl oyster increased from the reproductive period to the beginning of the fattening period. The changes in potassium and phosphate content also agreed with that of the total ash content. These facts suggest that these elements may be related to sexual activity. 
From February to March the amount of iron reached a maximum. Since this element has been known as the component of the respiratory enzymes, it may play some significant role in the transformation of certain organic substances such as glycogen and lipids, in the pearl oyster.

It has already been known that taurin, an amino sulphuric acid, is the characteristic substance of the mollusks (9). The content of sulphate may be connected with taurin and other sulphuric esters of carbohydrate (10) which compose the mucus.

Sodium, magnesium and chloride are less variable at the content. The content of calcium in the meat was observed to decrease in the autumn when the shell grew in this season.

From the analytical results of the pearl, mother-of-pearl of the shell and the mucus of the pearl oyster, non-cooperation of phosphate is inferred in the process of calcification of the pearl oyster. (see Table X).

\section{Table X.}

Analytical Results of Pearl, Shell and Mucus of the Pearl Oyster

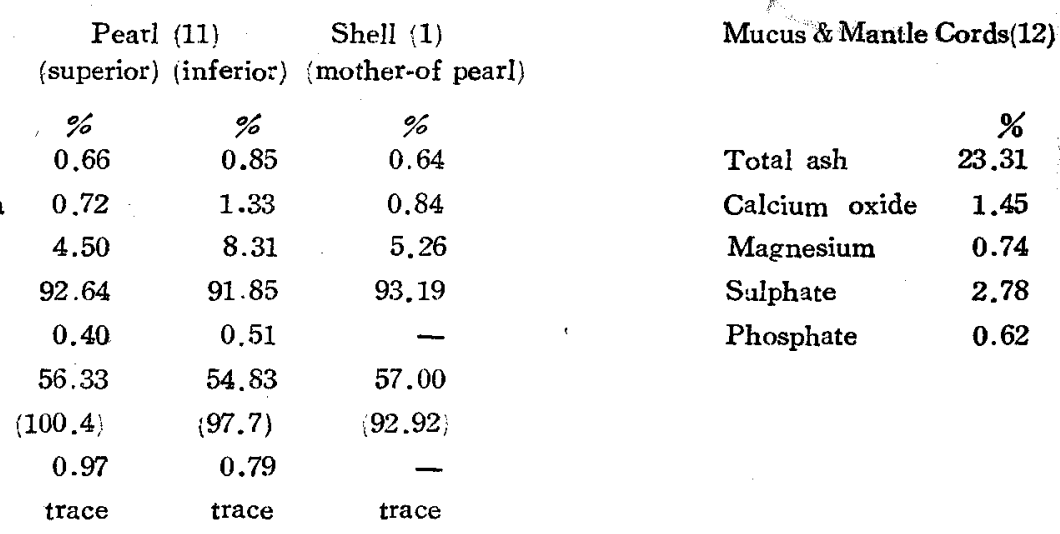

In stead of cooperation of phosphate in the vertebrate, transportation of calcium at the formation of the pearl and of the shell in the pearl oyster would be carried on with participation of certain proteins of acidic nature in the mucus secreted from mucus cell of mantle cords.

The authors wish to express their hearty thanks to Prof. D. MIYADI and the members of the Seto Marine Biological Laboratory, Kyoto Univ., and also to Dr. Y. Marsul, the chief of the Nippon Institute for Scientific Research on Pearl, for their kind helps in these experiments. 


\section{BIBLIOGRAPHY}

(1) J. OGUSHI, "Studies on Pearl", (in Japanese), (1938).

(2) A. R. CAHN, "Pearl Culture in Japan", G.H.Q., N.R.S. Report No. 122, (1949).

(3) S. TANAKA and H. HATANO, J. Chem. Soc. Japan, (in press).

(4) "Method of Analysis of the Association of Official Agricultural Chemist", (1932).

(5) F. PREGL, "Die Quantitative Organische Mikroanalyse", S. 105, (1935).

(6) A. C. BRowNE, "Handbook of Sugar Analysis", p. 578, (1912); "Sugar Analysis ", p. 867, (1948).

(7) S. MORI, Jap. J. Malac. (in Japanese), 15, 46, (1948).

(8) G. KLEIN, "Handbuch der Pfanzenanalyse", (1932).

(9) OTANI and FujikaWA, "Chemistry of Mollusks", (in Japanese), p. 41, (1934).

(10) T. SoDA et al., J. Chem. Soc. Japan, 57, 981, (1936); ibid., 61, 683, (1940); Bull. Chem. Soc. Japan, 13, 652, (1938).

(11) S. TANAKA and H. Hatano, J. Chem. Soc. Japan, (in press).

(12) OKUDA and TAKEUCHI, J. Chem. Soc. Japan, 38, 819, (1919). 